Open Access

\title{
The Pro12Ala polymorphism in the PPARY2 gene is not associated with an increased risk of NAFLD in Iranian patients with type 2 diabetes mellitus
}

\author{
Leila Saremi ${ }^{1}$, Shirin Lotfipanah ${ }^{2}$, Masumeh Mohammadi ${ }^{1}$, Hassan Hosseinzadeh ${ }^{3}$, Mina Fathi-Kazerooni ${ }^{4}$, \\ Behrooz Johari ${ }^{5}$ and Zohreh Saltanatpour ${ }^{6^{*}}$
}

\author{
* Correspondence: z-saltanatpour@ \\ razi.tums.ac.ir; zohre_saltanatpour@ \\ yahoo.com \\ ${ }^{6}$ Medical Genetic Center, \\ Endocrinology and Metabolism \\ Research Institute (EMRI), Tehran \\ University of Medical Sciences \\ (TUMS), Tehran, Iran \\ Full list of author information is \\ available at the end of the article
}

\begin{abstract}
Background: The peroxisome proliferator-activated receptors (PPARs) are ligandactivated transcription factors that belong to the nuclear hormone receptor superfamily. Several studies have demonstrated a significant association between Pro12Ala polymorphism of the PPARY2 gene and metabolic disorders. Therefore, this study aimed to evaluate the association of Pro12Ala polymorphism with increased risk of NAFLD in Iranian patients with type 2 diabetes mellitus.
\end{abstract}

Methods: This cross-sectional study was performed on 145 healthy control subjects and 145 NAFLD patients with a history of type 2 diabetes. Pro12Ala polymorphism genotyping was performed using PCR-restriction fragment length polymorphism (RFLP) technique with the Bs1/ restriction enzyme.

Results: Our results demonstrated that CC and GG genotypes of Pro12Ala were found in the participants, but there was no statistically significant difference between NAFLD patients and healthy controls $\left(P=0.64\right.$ and $\left.X^{2}=0.21\right)$.

Conclusion: This study suggests that Pro12Ala polymorphism of the PPARY2 gene cannot be considered as a risk factor for NAFLD in the Iranian population.

Keywords: Pro12Ala polymorphism, PPARY2 gene, NAFLD, Type 2 diabetes mellitus

\section{Introduction}

Nonalcoholic fatty liver disease (NAFLD) is one of the most prevalent forms of progressive liver disease, which is characterized by obesity, dyslipidemia, type 2 diabetes mellitus (T2DM), hypercholesterolemia, hypertension, insulin resistance, cirrhosis, liver failure and hepatocellular carcinoma [1-3]. NAFLD is highly prevalent in T2DM and the prevalence of NAFLD in obese adults with T2DM has been estimated to be greater than $70 \%$. The most important treatment method of NAFLD is to increase insulin sensitivity by lifestyle changes [2-10]. Epidemiological, familial, and twin studies have suggested that genetic background and environmental factors play important roles in the pathogenesis of NAFLD as multifactorial diseases [8-16].

The peroxisome proliferator-activated receptors (PPARs) are ligand-activated transcription factors which belong to the nuclear hormone receptor superfamily and

(c) The Author(s). 2019 Open Access This article is distributed under the terms of the Creative Commons Attribution 4.0 International License (http://creativecommons.org/licenses/by/4.0/), which permits unrestricted use, distribution, and reproduction in any medium, provided you give appropriate credit to the original author(s) and the source, provide a link to the Creative Commons license, and indicate if changes were made. The Creative Commons Public Domain Dedication waiver (http://creativecommons.org/ publicdomain/zero/1.0/) applies to the data made available in this article, unless otherwise stated. 
consist of three subtypes, each of them encoded by different genes: PPAR $\alpha$ (NR1C1), PPARY (NR1C3) and PPAR $(\mathrm{NP1C} 2)$ [3, 16-18]. The PPAR $\gamma$ receptor plays a key role in the regulation of adipocyte-specific genes, lipid metabolism, glucose homeostasis, insulin sensitivity and blood pressure $[2,16,19,20]$. The human PPAR $\gamma$ gene, located on chromosome 3p25, has nine exons (A1, A2, B, exons 1-6 from 5' to 3' direction), and its protein product has three isoforms, PPAR $\gamma 1$, PPAR- $\gamma 2$ and PPAR $\gamma 3$, which are produced by mRNA alternative splicing of PPAR $\gamma[4,20,21]$. Among them, the PPAR $-\gamma 2$ isoform is expressed predominantly in the adipose tissue, where it plays an important role in regulating adipogenic differentiation and as a mediator of insulin sensitivity [20, 22-25]. The single nucleotide polymorphisms (SNPs) of the PPAR- $\gamma 2$ gene have been shown to be associated with susceptibility to several metabolic disorders and many studies have shown a strong relationship between this gene and the occurrence of T2DM in many populations [9, 10, 26, 27]. The polymorphism rs1801282 (c.34C > G) on codon 12 of exon B of the PPAR- $\gamma 2$ gene, which leads to the substitution of proline with alanine (Pro12Ala), was found to be associated with higher insulin sensitivity, lower body mass index (BMI), decreased risk of T2DM and diabetic nephropathy [28-32]. Several investigations have shown that there is an association between this polymorphism and increased risk of metabolic disorders in various populations. However, published results on the genetic associations of this SNP with NAFLD are controversial and inconclusive [33-36]. This study aimed to elucidate the association of Pro12Ala with increased risk of NAFLD in Iranian patients with type 2 diabetes mellitus as a common metabolic disorder.

\section{Material and methods}

\section{Subjects}

This case-control study was based on 290 individuals of Iranian ancestry. The patient group included 145 patients with biopsy-proven NAFLD with a history of type 2 diabetes attending the Shahid Rajaei Cardiovascular Medical and Research Center in Tehran, Iran. All patients were recruited by use of liver biopsy. Only patients with a negative history of alcohol consumption and other known causes of chronic liver disease (e.g. autoimmune hepatitis, viral hepatitis, use of hepatotoxic medications such as antibiotics, glucocorticoids, tamoxifen or other anti-neoplastic drugs) were analyzed [5, 37]. Patients with unavailable liver ultrasound examination were excluded from the study. The controls were 145 individuals representing a general population sample from the same geographical region who had normal abdominal ultrasonography. Participants were matched for sex and age and numbers of men and women were equal in both groups. All participants gave written informed consent, and this study conforms to the principles of the Declaration of Helsinki. Both patient and control subjects' characteristics including gender and age are shown in Table 1.

Table 1 Characteristics of study population

\begin{tabular}{lccc}
\hline Characteristics & Patients & Controls & $P$ value \\
\hline Total & 145 & 145 & - \\
Men & 73 & 73 & 1.0 \\
Women & 72 & 72 & \\
Mean age & $53.9 \pm 9$ & $51.3 \pm 10$ & 0.98 \\
\hline
\end{tabular}


Clinical and laboratory findings were collected for each NAFLD patient from the clinical charts, including fasting blood sugar (FBS), BMI, creatine (Cr), total serum cholesterol (TC), triglyceride (TG), low-density lipoproteins (LDL) cholesterol, high-density lipoproteins (HDL) cholesterol, hemoglobin A1c (HbA1c), and microalbumin.

\section{DNA extraction and molecular genotyping}

Genomic DNA was isolated from peripheral blood leukocytes using Bioneer's DNA extraction kit (Bioneer, Daejeon, Korea). Pro12Ala (CCG-GCG) alleles were determined by PCR-restriction fragment length polymorphism (RFLP) analysis using Bs $1 I$ restriction enzyme.

Forward and reverse primer sequences were $5^{\prime}$ - TGTCTTGACTCATGGGTGT ATTC-3' and 5' - ATCAGTGAAGGAACCGCTTT-3', respectively. Each PCR was performed in a final volume of $25 \mu \mathrm{l}$, including $100 \mathrm{ng}$ of genomic DNA, $0.5 \mu \mathrm{l}$ of each primer (10 pmol), $0.5 \mu \mathrm{l}$ of dNTP, $0.8 \mu \mathrm{l}$ of $\mathrm{MgCl}_{2}, 2.5 \mu \mathrm{l}$ of 10x PCR buffer and 2 units of Taq polymerase. The PCR conditions were as follows: initial denaturation at $95^{\circ} \mathrm{C}$ for $5 \mathrm{~min}$, then 35 cycles of $95^{\circ} \mathrm{C}$ for $30 \mathrm{~s}$, annealing at $57^{\circ} \mathrm{C}$ for $30 \mathrm{~s}$, extension at $72{ }^{\circ} \mathrm{C}$ for $30 \mathrm{~s}$. This was followed by final extension at $72{ }^{\circ} \mathrm{C}$ for $5 \mathrm{~min}$. The $185 \mathrm{bp}$ amplified fragment was digested by restriction endonuclease Bs $1 I$ (Fermentas). The restriction fragments were separated by electrophoresis on a $2 \%$ agarose gel. Gel was stained with ethidium bromide and photographed by UV photography.

\section{Statistical analysis}

The data were analyzed using the SPSS 12.0 statistical software (SPSS, Chicago, IL, USA). Using the $\chi^{2}$ test, genotype and allele frequencies in the NAFLD and control subjects were compared. Student's $t$ test was applied to detect differences between groups with various genotypes regarding other variables such as age, FBS TG, TC, LDL, HDL and HbA1c. Odds ratios (OR) and their 95\% confidence intervals (CI) were calculated. The associations between Pro12Ala polymorphism in the PPAR $\gamma 2$ gene with NAFLD and clinical and biochemical variables were evaluated. Data are presented as mean \pm standard deviation (SD) and $P$ values of less than 0.05 were considered significant for all tests.

\section{Results}

Digestion of PCR amplifications of the PPAR 2 gene with Bs1I gave different patterns, as shown in Fig. 1.

The allelic and genotypic frequencies of the Pro12Ala PPAR 2 gene SNPs in patient and control subjects are shown in Table 2 . As presented, there is no statistically significant difference regarding the allelic and genotypic frequencies of Pro12Ala PPAR 2 gene SNPs between the NAFLD patients and healthy control subjects $\left(P=0.64\right.$ and $\left.\chi^{2}=0.21\right)$.

The results showed no significant difference between the Pro12Ala carriers and wild-type individuals in the biochemical variables including BMI, FBS, Cr, lipid profile (TG, TC, HDL-C, and LDL-C), HbA1c, and micro albumin levels (data not shown).

\section{Discussion}

In this study, the association of PPAR 2 gene SNP Pro12Ala and increased risk of NAFLD was evaluated in patients with type 2 diabetes mellitus. Our results demonstrate that the 


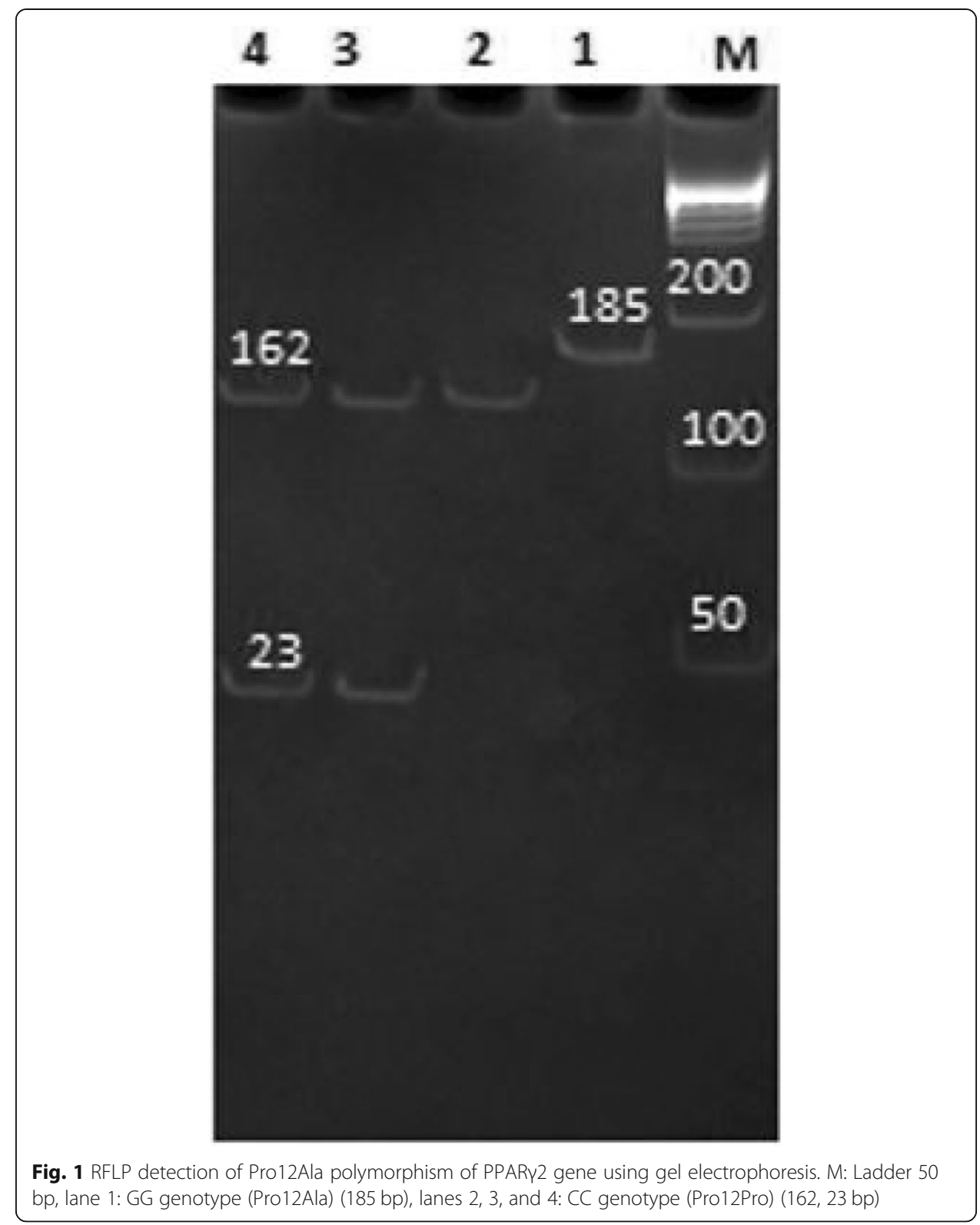

Table 2 Genotypic association of the Pro12Ala polymorphism with NAFLD

\begin{tabular}{lcccc}
\hline Variable & \multicolumn{2}{c}{ Genotype } & OR (95\% Cl) & $P$-value \\
NAFLD patients & $87(60 \%)$ & $58(40 \%)$ & $1.92(0.742-1.917)$ & 0.468 \\
Control subjects & $93(64.1 \%)$ & $52(35.9 \%)$ & & \\
& & & OR (95\% Cl) & $P$-value \\
& C N (\%) & G N (\%) & & \\
NAFLD patients & $174(80 \%)$ & $116(20 \%)$ & $1.192(0.852-1.668)$ & 0.304 \\
Control subjects & $186(82 \%)$ & $104(18 \%)$ & & \\
\hline
\end{tabular}


polymorphism rs1801282 (c.34C > G, Pro12Ala) in the PPAR 2 gene is not associated with increased susceptibility to NAFLD in the Iranian population. Therefore, SNP Pro12Ala cannot be a genetic marker of NAFLD in this population.

NAFLD is independently associated with T2DM, obesity and metabolic syndrome, and the accumulation of fatty acid in the liver impairs insulin sensitivity. It has been hypothesized that the genetic variations (SNPs) found in metabolic syndrome patients may be related to NAFLD [38-41]. PPARY is involved in regulation of adipogenic differentiation, lipid metabolism, insulin sensitivity and hepatic steatosis [42]. Thus, PPARY is a promising candidate gene for several metabolic syndromes including T2DM, obesity, and NAFLD. However, the effect of PPAR $\gamma$ gene SNPs on the pathogenesis of NAFLD has not been clearly documented. Therefore, investigating the relationship between Pro12Ala PPAR 2 gene SNPs and increased susceptibility to NAFLD is important.

According to our results, the Pro12Ala SNP does not induce NAFLD in the Iranian population. Since the PPAR $\gamma$ gene contains several polymorphisms, other genetic variations may affect expression of the related molecule and be associated with NAFLD, which needs to be evaluated by further investigations.

However, the associations of Pro12Ala polymorphism with NAFLD have been reported to be varied in different populations and ethnic groups. For example, Gupta et al. investigated the Pro12Ala variant in 98 NAFLD patients and 280 matched controls and found that the Pro12Ala polymorphism was significantly associated with NAFLD in an Indian population [16]. Gawrieh et al., by evaluation of an American population, demonstrated that the SNP was associated with histologically advanced NAFLD [43]. Yang et al. revealed that Pro/Pro genotype of Pro12Ala was an increased risk factor for the development of NAFLD in Chinese patients [44]. A meta-analysis also demonstrated that the Pro12Ala variation of PPAR $\gamma 2$ was associated with susceptibility to NAFLD in East Asians, but not in European populations [13]. Bhatt et al. in a study with 162 Asian NAFLD patients and 173 controls observed that Pro12Ala SNP not only was associated with NAFLD but also was associated with alkaline phosphatase, higher serum TG, and waist-hip ratio [45].

Although the mentioned investigations revealed that PPAR gene polymorphism was significantly associated with NAFLD in some population, Dongiovanni et al. observed that the PPAR- $\gamma 2$ Pro12Ala frequency was not significantly different between NAFLD patients and healthy controls, in a study enrolling 202 Italian patients and 346 matched controls [12]. Rey et al. also reported that the incidence of the Ala12 mutant in German patients with NAFLD was not significantly different from healthy controls, and no significant difference was observed in histological inflammation in NAFLD [46]. Cao et al. studied the effect of Pro12Ala PPAR 2 gene SNPs in Chinese patients with NAFLD, including 169 NAFLD patients and 699 healthy subjects. Their analysis showed that the allele frequency was not significantly different between the two groups $(p>0.05)$ [4]. Domenici et al. found that Pro12Ala polymorphism was not associated with clinical, laboratory and histological parameters in NAFLD patients [8]. In the study by Chen et al., no association was found between PPAR- $\gamma 2$ Pro12Ala substitution and NAFLD, and no significant difference was observed between this polymorphism and physiological variables [2]. Results from the meta-analysis of Sahebkar et al. indicated that Pro12Ala variation of PPAR 2 was not associated with NAFLD risk [47]. 
Generally, it seems that there is a significant controversy regarding the roles of PPARY gene polymorphism in NAFLD pathogenesis. These consistencies could be the result of the different ethnic structure, referral and ascertainment biases, inadequate sample size, lack of mediators' adjustment, or publication bias.

A possible limitation of our study was the small sample size, so further larger studies are required for confirmation.

In conclusion, the results of this study showed that Pro12Ala polymorphism of the PPARY2 gene is not associated with increased susceptibility to NAFLD in the Iranian population. However, more studies with a larger sample size are needed to confirm this.

\begin{abstract}
Abbreviations
NAFLD: Non-alcoholic fatty liver disease; PPARs: Peroxisome proliferator-activated receptors; RFLP: Restriction fragment length polymorphism; T2DM: Type 2 diabetes mellitus
\end{abstract}

\title{
Acknowledgments
}

We thank all participants for contributing to our study. Special thanks to the staff of the referral centers of Shahid Rajaei Cardiovascular Medical and Research Center in Tehran, Iran.

Funding

This work was supported by the Tehran University of Medical Sciences, Tehran, Iran.

\section{Availability of data and materials}

The dataset supporting the conclusions of this article is included within the article. Also, the DNA samples of studied subjects and molecular materials are available for sharing.

\section{Authors' contributions}

LS and ZS were in charge of samples collection, experimental design and PCR. SL and MM contributed equally performed and designed experiments, analyzed data, and generated Figs. BJ and HH were in charge of idea and concept of the paper and also performed studies on healthy controls and subjects' collected and paper writing. ZS and MF were assisted in supervision and generated figures and edited the manuscript. All authors read and approved the final manuscript.

\section{Ethics approval and consent to participate}

Institutional Ethics committees of Islamic Azad University and Southwest Medical University approved the study. This study was conducted in accordance with the Declaration of Helsinki (1964). Informed consent was obtained from all study participants. All study participants registered in the analysis were recruited from Shahid Rajaei Cardiovascular Medical and Research Center in Tehran, Iran. The informed consent explains to patients that they have a right to leave the study at any time.

\section{Consent for publication}

Not applicable.

\section{Competing interests}

The authors declare that they have no competing interests.

\section{Publisher's Note}

Springer Nature remains neutral with regard to jurisdictional claims in published maps and institutional affiliations.

\section{Author details}

${ }^{1}$ Department of Biology, Science and Research Branch, Islamic Azad University, Tehran, Iran. ${ }^{2}$ Farhangian University, Shahid Mofatteh Teacher Education Paradise, Tehran, Iran. ${ }^{3}$ Department of Biology, Faculty of Science, Yazd University, Yazd, Iran. ${ }^{4}$ Department of Molecular Medicine, School of Advanced Technologies in Medicine, Tehran University of Medical Sciences, Tehran, Iran. ${ }^{5}$ Department of Medical Biotechnology, School of Medicine, Zanjan University of Medical Sciences, Zanjan, Iran. ${ }^{6}$ Medical Genetic Center, Endocrinology and Metabolism Research Institute (EMRI), Tehran University of Medical Sciences (TUMS), Tehran, Iran.

Received: 7 April 2018 Accepted: 30 January 2019

Published online: 26 June 2019

\section{References}

1. Wood KL, Miller MH, Dillon JF. Systematic review of genetic association studies involving histologically confirmed nonalcoholic fatty liver disease. BMJ Open Gastroenterol. 2015;2(1):e000019.

2. Chen S-H, Ying L, Wu C, Wang Q, Li Y-M. Pro12Ala substitution in the peroxisome proliferator-activated receptor gamma (PPARY) gene and non-alcoholic fatty liver disease. Arch Biol Sci. 2013;65(3):809-14.

3. Dongiovanni P, Valenti L. Peroxisome proliferator-activated receptor genetic polymorphisms and nonalcoholic fatty liver disease: any role in disease susceptibility? PPAR Res. 2013;2013:452061. 
4. Cao C-Y, Li Y-Y, Zhou Y-J, Nie Y-Q, Y-JY W. The C-681G polymorphism of the PPAR-Y gene is associated with susceptibility to non-alcoholic fatty liver disease. Tohoku J Exp Med. 2012;227(4):253-62.

5. Saremi L, Lotfipanah S, Mohammadi M, Hosseinzadeh H, Sayad A, Saltanatpour Z. Association of HFE gene mutations with nonalcoholic fatty liver disease in the Iranian population. Cell Mol Biol (Noisy-le-grand). 2016;62(12):123.

6. Stefan N, Haring HU. The metabolically benign and malignant fatty liver. Diabetes2011. 2011:60.

7. LaBrecque DR, Abbas Z, Anania F, Ferenci P, Khan AG, Goh K-L, et al. World gastroenterology organisation global guidelines: nonalcoholic fatty liver disease and nonalcoholic steatohepatitis. J Clin Gastroenterol. 2014;48(6):467-73.

8. Domenici FA, Brochado MJF, Martinelli AdLC, Zucoloto S, da Cunha SFdC, Vannucchi H. Peroxisome proliferatoractivated receptors alpha and gamma2 polymorphisms in nonalcoholic fatty liver disease: a study in Brazilian patients. Gene 2013;529(2):326-331.

9. Skrypnik D, Ratajczak M, Karolkiewicz J, Madry E, Pupek-Musialik D, Hansdorfer-Korzon R, Walkowiak J, Jakubowski H, Bogda-nski P. Effects of endurance and endurance-strength exercise on biochemical parameters of liver function in women with abdominal obesity. Biomed Pharmacother. 2016;80:1-7.

10. Skrypnik K, Suliburska J, Skrypnik D, Pilarski L, Reguła J, Bogdański P. The genetic basis of obesity complications. Acta Sci Pol Technol Aliment. 2017;16(1):83-91.

11. Tolman KG, Dalpiaz AS. Treatment of non-alcoholic fatty liver disease. Ther Clin Risk Manag. 2007:3(6):1153.

12. Dongiovanni P, Rametta R, Fracanzani AL, Benedan L, Borroni V, Maggioni P, et al. Lack of association between peroxisome proliferator-activated receptors alpha and gamma2 polymorphisms and progressive liver damage in patients with non-alcoholic fatty liver disease: a case control study. BMC Gastroenterol. 2010;10(1):102.

13. Lee $\mathrm{YH}$, Bae S-C, Song GG. Meta-analysis of associations between the peroxisome proliferator-activated receptor- $\gamma$ Pro12Ala polymorphism and susceptibility to nonalcoholic fatty liver disease, rheumatoid arthritis, and psoriatic arthritis. Genet Test Mol Biomarkers. 2014;18(5):341-8.

14. Schwimmer JB, Celedon MA, Lavine JE, Salem R, Campbell N, Schork NJ, et al. Heritability of nonalcoholic fatty liver disease. Gastroenterology. 2009;136(5):1585-92.

15. Guerrero R, Vega GL, Grundy SM, Browning JD. Ethnic differences in hepatic steatosis: an insulin resistance paradox? Hepatology. 2009;49(3):791-801.

16. Gupta A, Chaudhory A, Pande C, Sakhuja P, Singh Y, Basir S, et al. Peroxisome proliferators-activated receptor $\gamma 2$ Pro12Ala variant is associated with body mass index in non-alcoholic fatty liver disease patients. Hepatol Int. 2011;5(1): 575-80.

17. Semple RK, Chatterjee VKK, O'Rahilly S. PPARY and human metabolic disease. J Clin Invest. 2006;116(3):581-9.

18. Kallwitz ER, McLachlan A, Cotler SJ. Role of peroxisome proliferators-activated receptors in the pathogenesis and treatment of nonalcoholic fatty liver disease. World J Gastroenterol. 2008;14(1):22.

19. Beaven SW, Tontonoz P. Nuclear receptors in lipid metabolism: targeting the heart of dyslipidemia. Annu Rev Med. 2006:57:313-29.

20. Motavallian A, Andalib S, Vaseghi G, Mirmohammad-Sadeghi H, Amini M. Association between PRO12ALA polymorphism of the PPAR-y2 gene and type 2 diabetes mellitus in Iranian patients. Indian J Hum Genet. 2013;19(2):239.

21. Tavares V, Hirata R, Rodrigues A, Monte O, Salles J, Scallissi N, et al. Effect of the peroxisome proliferator-activated receptor-gamma C161T polymorphism on lipid profile in Brazilian patients with type 2 diabetes mellitus. J Endocrinol Investig. 2005;28(2):129-36.

22. Bhatt SP, Misra A, Sharma M, Luthra K, Guleria R, Pandey RM, et al. Ala/ala genotype of Pro12Ala polymorphism in the peroxisome proliferator-activated receptor- $\gamma 2$ gene is associated with obesity and insulin resistance in Asian Indians. Diabetes Technol Ther. 2012;14(9):828-34.

23. Priya SS, Sankaran R, Ramalingam S, Sairam T, Somasundaram L. Genotype phenotype correlation of genetic polymorphism of PPAR gamma gene and Therapeutic response to pioglitazone in type 2 diabetes mellitus-a pilot study. J Clin Diagn Res. 2016;10(2):FC11.

24. Auwerx J. PPARY, the ultimate thrifty gene. Diabetologia. 1999:42(9):1033-49.

25. Stumvoll M, Häring H. The peroxisome proliferator-activated receptor- $\gamma 2$ Pro12Ala polymorphism. Diabetes. 2002;51(8): 2341-7.

26. Saremi L, Saremi M, Lotfipanah S, Imani S, Zhang T, Fu J. Relation between PPARGC1A gene polymorphisms with the increased risk of coronary artery disease among patients with type 2 diabetes mellitus in Iran. Gen Endocrinol. 2015; 11(1):13-7.

27. Saremi L, Saremi M, Lotfipanah S, Imani S, Fu J, Zhang T. Correlation between HFE gene polymorphisms and increased risk of coronary artery disease among patients with type 2 diabetes in Iran. Turk J Med Sci. 2016 Apr 19;46(3):590-6.

28. Caramori ML, Canani LH, Costa LA, Gross JL. The human peroxisome proliferator-activated receptor $\gamma 2$ (PPARY2) Pro12Ala polymorphism is associated with decreased risk of diabetic nephropathy in patients with type 2 diabetes. Diabetes. 2003;52(12):3010-3.

29. Tönjes A, Scholz M, Loeffler M, Stumvoll M. Association of Pro12Ala polymorphism in peroxisome proliferator-activated receptor $\gamma$ with pre-diabetic phenotypes. Diabetes Care. 2006;29(11):2489-97.

30. Hegele RA, Cao H, Harris SB, Zinman B, Hanley AJ, Anderson CM. Peroxisome proliferator-activated receptor- $\gamma 2$ P12A and type 2 diabetes in Canadian Oji-Cree 1. J Clin Endocrinol Metab. 2000;85(5):2014-9.

31. Deeb SS, Fajas L, Nemoto M, Pihlajamäki J, Mykkänen L, Kuusisto J, et al. A Pro12Ala substitution in PPARy2 associated with decreased receptor activity, lower body mass index and improved insulin sensitivity. Nat Genet. 1998;20(3):284-7.

32. Mohammadi-Asl J, Soheil-Nezhad A, Saremi L, Rahim F. Association of PPARG gene polymorphism (Pro12Ala) with type 2 diabetes in the Iranian population. HealthMed. 2013;7(4):1329-33.

33. Butt C, Gladman D, Rahman P. PPAR-gamma gene polymorphisms and psoriatic arthritis. J Rheumatol. 2006;33(8):1631-3.

34. El-Sohemy A, Cornelis MC, Park Y-W, Bae S-C. Catalase and PPARY2 genotype and risk of rheumatoid arthritis in Koreans. Rheumatol Int. 2006;26(5):388-92.

35. Terauchi Y. PPARgamma and metabolic syndrome. Rinsho byori Jpn J Clin Pathol. 2007:55(5):447-51.

36. Pan X, Song X, Wang L, Li L, Ying B. Association of the Pro12Ala polymorphism in peroxisome proliferators activated receptor-gamma gene with rheumatoid arthritis in Sichuan Province of China. Zhonghua yi xue yi chuan xue za zhi= Zhonghua yixue yichuanxue zazhi= Chin J Med Genet. 2009;26(1):87-90. 
37. Saremi I, Saremi M, Lotfipanah S, Imani S, Zhang T, Fu J. Relationship between ppaRGCla gene polymoRphisms with the inCReased risk of CoRonaRy aRteRy disease among patients with type 2 diabetes mellitus in iRan. Acta Endocrinologica-Bucharest. 2015;11(1):13-7.

38. Willner IR, Waters B, Patil SR, Reuben A, Morelli J, Riely CA. Ninety patients with nonalcoholic steatohepatitis: insulin resistance, familial tendency, and severity of disease. Am J Gastroenterol. 2001;96(10):2957-61.

39. de Alwis NMW, Day CP. Genetics of alcoholic liver disease and nonalcoholic fatty liver disease. Semin Liver Dis; 2007: Copyright@ 2007 by Thieme Medical Publishers, Inc., 333 Seventh Avenue, New York, NY 10001, USA.; 2007. p. 044-54.

40. Méndez-Sánchez N, Arrese M, Zamora-Valdés D, Uribe M. Current concepts in the pathogenesis of nonalcoholic fatty liver disease. Liver Int. 2007;27(4):423-33.

41. Skrypnik K, Bogdański P, Łoniewski I, Reguła J, Suliburska J. Effect of probiotic supplementation on liver function and lipid statuse in rats. Acta Sci Pol Technol Aliment. 2018;17(2):185-92.

42. Lee YH, Rho YH, Choi SJ, Ji JD, Song GG. Association of TNF-alpha-308 G/a polymorphism with responsiveness to TNFa-blockers in rheumatoid arthritis: a meta-analysis. Rheumatol Int. 2006;27(2):157-61.

43. Gawrieh S, Marion MC, Komorowski R, Wallace J, Charlton M, Kissebah A, et al. Genetic variation in the peroxisome proliferator activated receptor-gamma gene is associated with histologically advanced NAFLD. Dig Dis Sci. 2012;57(4):952-7.

44. Yang Z, Wen J, Li Q, Tao X, Ye Z, He M, et al. PPARG gene Pro12Ala variant contributes to the development of nonalcoholic fatty liver in middle-aged and older Chinese population. Mol Cell Endocrinol. 2012;348(1):255-9.

45. Bhatt SP, Nigam P, Misra A, Guleria R, Luthra K, Pandey RM, et al. Association of peroxisome proliferator activated receptor-y gene with non-alcoholic fatty liver disease in Asian Indians residing in North India. Gene. 2013;512(1):143-7.

46. Rey JW, Noetel A, Hardt A, Canbay A, Alakus H, Zur Hausen A, et al. Pro12Ala polymorphism of the peroxisome proliferator-activated receptor gamma2 in patients with fatty liver diseases. World I Gastroenterol. 2010;16(46):5830-7.

47. Sahebkar A. Does PPARY2 gene Pro12Ala polymorphism affect nonalcoholic fatty liver disease risk? Evidence from a meta-analysis. DNA Cell Biol. 2013;32(4):188-98.

Ready to submit your research? Choose BMC and benefit from:

- fast, convenient online submission

- thorough peer review by experienced researchers in your field

- rapid publication on acceptance

- support for research data, including large and complex data types

- gold Open Access which fosters wider collaboration and increased citations

- maximum visibility for your research: over $100 \mathrm{M}$ website views per year

At $\mathrm{BMC}$, research is always in progress.

Learn more biomedcentral.com/submissions 